\title{
Proposing an Optimum Model for Time Estimation of Construction Projects in Iranian Gas Refineries
}

\author{
Abbas Naderpour ${ }^{1, a}$, Javad Majrouhi Sardroud ${ }^{1, b, *}$, and Masood Mofid ${ }^{2, c}$ \\ 1 Department of Civil Engineering, Islamic Azad University, Central Tehran Branch, Iran \\ 2 Department of Civil Engineering, Sharif University of Technology, Iran \\ E-mail: aAbas.Naderpour@gmail.com, bJ.Majrouhi.eng@Iauctb.ac.com (Corresponding author), \\ cM.Mofid@Sharif.ac.edu
}

\begin{abstract}
Time management can be effective in a project when the project schedule is based on comprehensive time scheduling. In the industries with complicated processes, many uncertainties and risks affect the timing of projects. Considering the very low reliability of the project planning in certainty-based approach, using more secure models for control and interact with uncertainty should be placed on the agenda. Iranian Gas Company has been using risk management to manage probable uncertainties in construction projects but in the field of possible uncertainties, actions are very scarce. This article aims to propose an optimum model based on the integrated risk management and fuzzy expert systems in order to provide comprehensive project time estimation and in this regard, reviews the results of the implementation of this model in construction projects of Iranian gas refineries. The results show that the proposed model increases the accuracy of time estimation about 8 to 24 percent.
\end{abstract}

Keywords: Time management, uncertainty, risk management, fuzzy expert systems.

ENGINEERING JOURNAL Volume 21 Issue 5

Received 13 January 2017

Accepted 28 March 2017

Published 29 September 2017

Online at http://www.engj.org/

DOI:10.4186/ej.2017.21.5.285 


\section{Introduction}

National Iranian Gas Company (NIGC) is one of the top ten gas companies in the gas industry in the Middle East and at present, it is comprised of 7 gas refineries. As the ongoing projects are directly or indirectly linked with continuous production in the gas refineries, the factors such as operational musts and site classification based on the HSE risks impose an unusual condition to project performance. There are two types of uncertainty that influence the project scheduling. The first type includes probable uncertainties and the second one covers possible uncertainties. Iranian gas refineries have been using risk techniques to manage probable uncertainties for many years but regard to non-probable uncertainties, actions are very scarce. This article aims to present a new model for managing uncertainties of construction project scheduling in gas refineries. So, as a preliminary step, there is a need to review some basic definitions and then the proposed model will be described.

\section{Uncertainty Management in Construction Projects}

Uncertainties that affect the project are based on the two theories: probability and possibility. These theories are analogous but they are different [1]. For example, consider protesting of rural residents against refinery road construction in a location close to them. For several reasons, the rural residents might (or might not) protest to stop the engineering work which reveals the likelihood of protest and its consequences. The impact of this uncertainty can be high if the protesters cut off the way to the site, and it could be very low if they accept the road construction. Thus, such types of uncertainties are probable because their impact and likelihood are due to probable uncertainty. In possibility theory, we do consider several possible outcomes at the same time and when a decision is made, it is built on the highest possibility event [2]. For example, assume that there is a need to establish an access to a new refinery that has no opponent. Therefore, the solution could be either enlarge the existing truck road, establish a new link with the highway, or transform the pathway into an access road or may be some other possible solutions; however, each possible solution has its own possibility which might be $100 \%$ each or $80 \%$, etc, and this possibility is not affected anyway by the possibility of the other options.

\section{Risk Management in Construction Projects}

Risk management is the process of identification, analysis and acceptance or mitigation of probable uncertainties in project decisions [3]. A project manager has to identify as many uncertainties as possible in risk management process (Fig. 1).

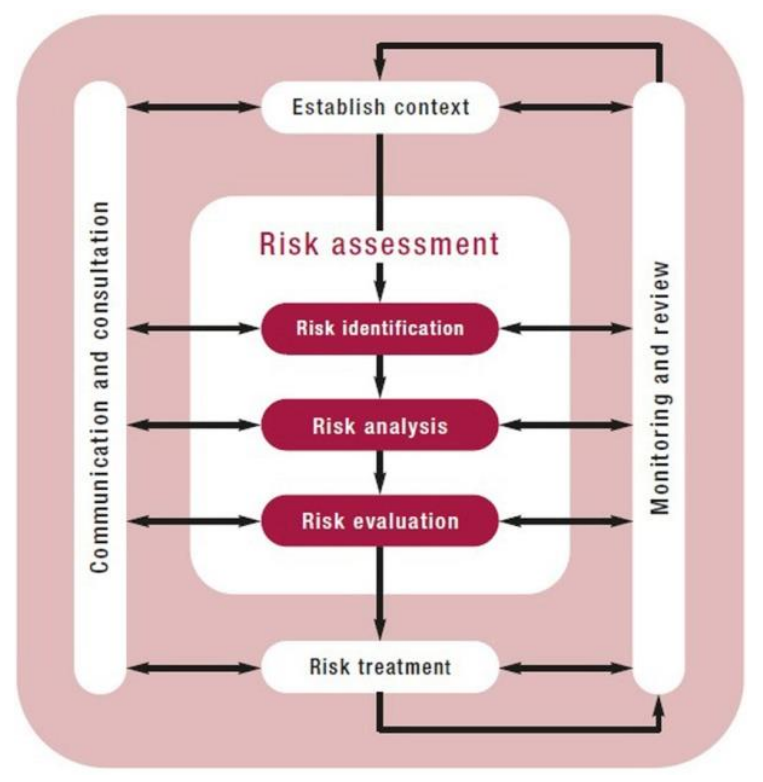

Fig. 1. Risk management process. 
A risk may or may not happen. This inherently probable uncertainty cannot be eliminated, but it can be made little clearer by clarifying the probability of occurrence of the risk, to get a better understanding of the consequences and alternatives if the risk occurs and determine the factors that influence the magnitude and likelihood of occurrence of the particular risk. This means that an uncertainty can never be completely eliminated, but it can be reduced to a level the project find tolerable. The authors of this paper have reviewed the literature on construction risk management that has been published in ten selected top quality journals from 1983 to 2015, It has been found that risk research, as applied in construction management discipline in the past three decades, can be divided into six broad fields, encompassing: (1) Risk Identifications; (2) Risk Approaches; (3) Risk Methods; (4) Risk Measurements; (5) Risk Integrations and (6) Risk Improvements (Fig. 2).

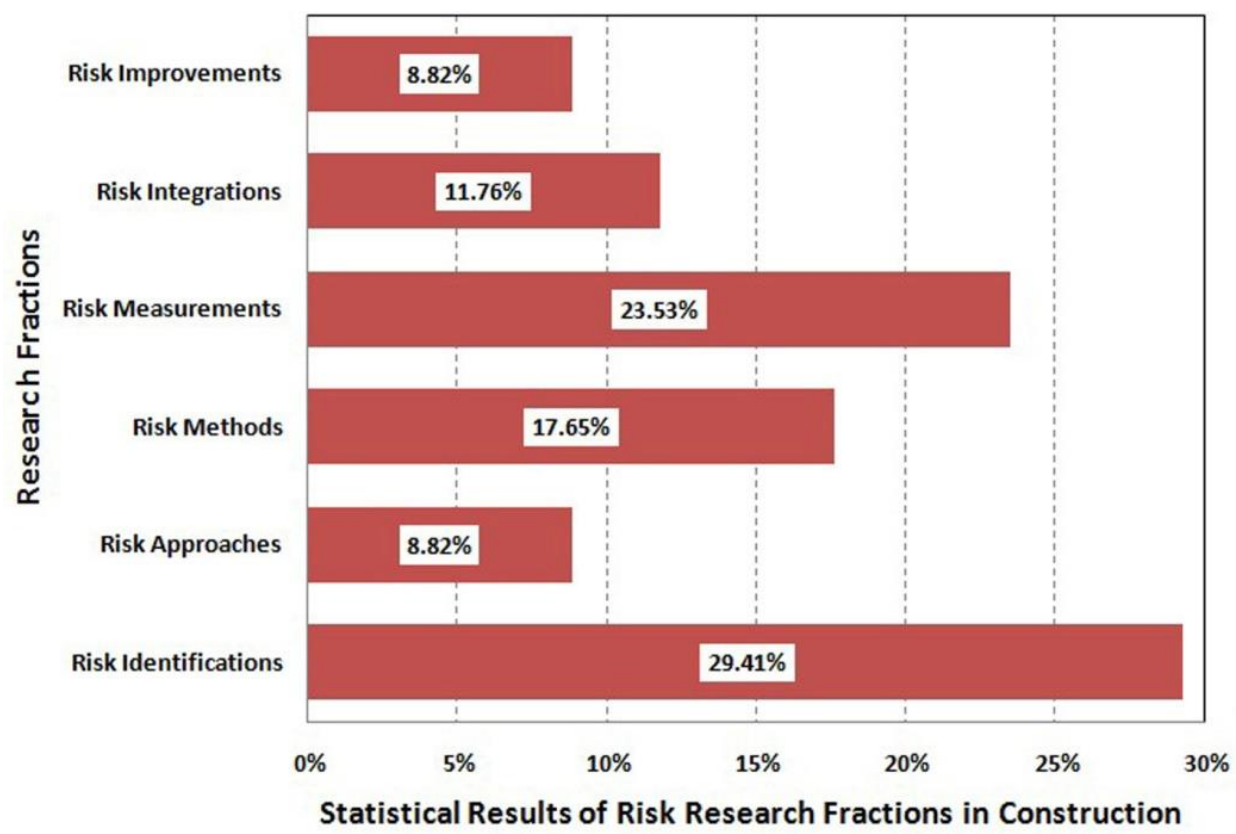

Fig. 2. Statistical results of risk research fractions in construction management.

\section{Possible Uncertainty Management in Construction Projects}

The old methods of project scheduling such as Critical Path Method (CPM) are still used commonly in many countries such as IRAN. But these methods are not successful in complicated projects [5]. The reason for this inefficiency is related to the inefficiency of old scheduling methods to manage project possible uncertainties. Sources of these uncertainties are wide ranging and have a fundamental effect on projects and project management. These sources are not confined to potential events and include lack of information, ambiguity, characteristics of project parties, tradeoffs between trust and control mechanisms, and varying agendas in different stages of the project lifecycle. It is Because of the high complexity in modeling and analysis of possible uncertainties in construction projects, artificial intelligence based methods and expert systems are utilized [6]. In this case, generally, two methods are recommended including Artificial Neural Network (ANN) and Fuzzy Logic. In neural networks, possible uncertainties could be eliminated by learning the ability of system [7]. While in the model needed to manage possible uncertainty, these uncertainties will always exist in the project and will remain up to the last stages. Thus, because of the high level of complexity and possible uncertainty associated with construction projects, the fuzzy expert systems are efficient. For example, consider the fuzzy project network indicated in Fig. 3. This project network illustrating an installation and commissioning of the Nitrogen package in one of the famous refineries located in South of Iran. The project time was estimated at 56 days in certainty-based approach. 


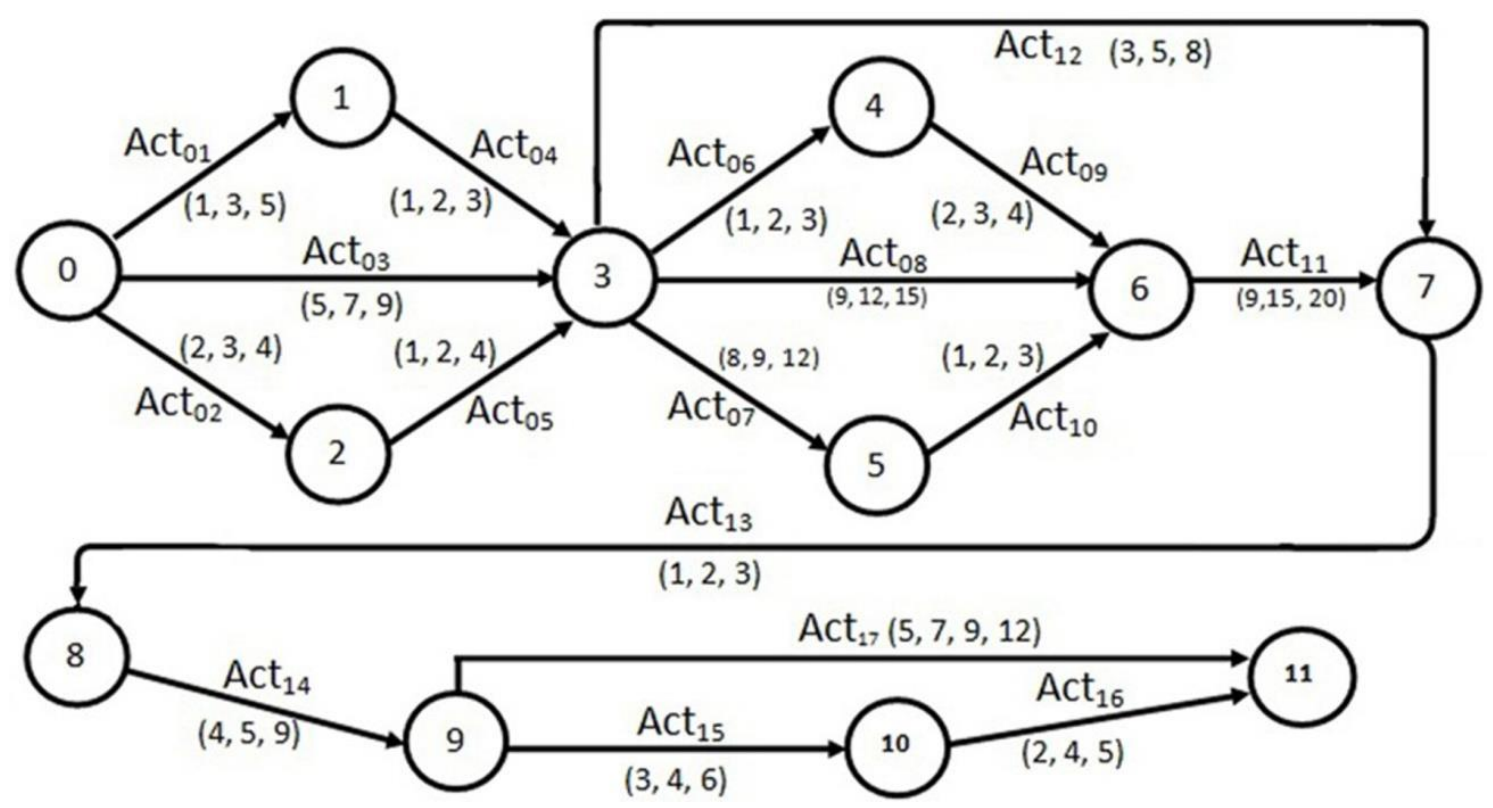

Fig. 3. CPM of the nitrogen package project by fuzzy approach.

The description of all activities regarding the mentioned project by Fuzzy approach is presented in Table 1 and a pictorial view of the project is shown in Fig. 4. In order to determine the project time by the fuzzy approach, it is necessary to rank the fuzzy numbers in scheduling network calculation and select the maximum. Since fuzzy numbers do not form a natural linear order (similar to real numbers) a key issue in applications of fuzzy set theory is how to compare fuzzy numbers. Various approaches have been developed for ranking fuzzy numbers up to now which are used according to the nature of the project. For calculation of this project time network, five ranking methods were considered [8-12].

Table 1. Nitrogen Package Project activities information.

\begin{tabular}{ccc}
\hline Activity ID & Activity Description & Activity Time (days) \\
\hline $0-1$ & Sending Samples to Laboratory & $(1,3,5)$ \\
\hline $0-2$ & Valves Procurement & $(2,3,4)$ \\
\hline $0-3$ & Site preparation & $(5,7,9)$ \\
\hline $1-3$ & Material Confirmation & $(1,2,3)$ \\
\hline $2-3$ & Valve Confirmation & $(1,2,4)$ \\
\hline $3-7$ & Valve Installation & $(3,5,8)$ \\
\hline $3-4$ & Evaporator Procurement & $(1,2,3)$ \\
\hline $3-5$ & Built-in Pipe Supports & $(8,9,12)$ \\
\hline $3-6$ & Built and Installation of Structures & $(9,12,15)$ \\
\hline $4-6$ & Evaporator Installation & $(2,3,4)$ \\
\hline $5-6$ & Installation of Pipe Supports & $(1,2,3)$ \\
\hline $6-7$ & Piping Installation & $(9,15,20)$ \\
\hline $7-8$ & Pre-commissioning Test & $(1,2,3)$ \\
\hline $8-9$ & Insulating & $(4,5,9)$ \\
\hline $9-10$ & Painting & $(3,4,6)$ \\
\hline $10-11$ & Cleaning of the Site & $(2,4,5)$ \\
\hline $9-11$ & Commissioning & $(5,7,9,12)$ \\
\hline
\end{tabular}




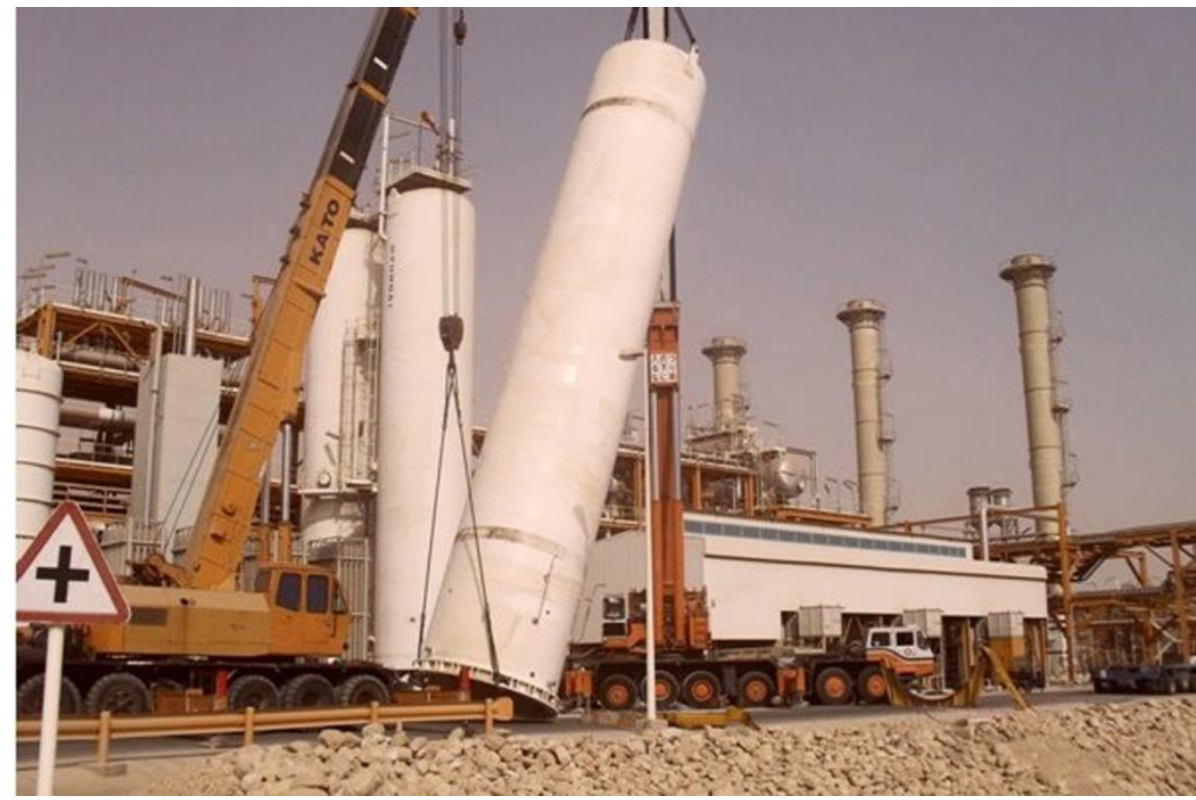

Fig. 4. Pictorial view of the Nitrogen Package Project.

As it could be seen from Table 1, 16 out of whole 17 activity times have triangular fuzzy type format and only the remaining one is in trapezoidal form. Equations 1 to 12 represent the stages of FCPM calculations of the project network. The calculations indicate that the project total time is the maximum of three fuzzy numbers (Eq. 12). Consequently, in order to determine the project time, it is necessary to rank the fuzzy numbers and select the maximum.

$$
\begin{aligned}
& \text { FES0 }=(0,0,0) \\
& \text { FES1 }=(0,0,0)+(1,3,5)=(1,3,5) \\
& \text { FES2 }=(0,0,0)+(2,3,4)=(2,3,4) \\
& \text { FES3 }=\operatorname{Max}((1,3,5)+(1,2,3),(2,3,4)+(1,2,4),(5,7,9))=(5,7,9) \\
& \text { FES4 }=(5,7,9)+(1,2,3)=(6,9,12) \\
& \text { FES5 }=(5,7,9)+(8,9,12)=(13,16,21) \\
& \text { FES6 }=\text { Max }((6,9,12)+(2,3,4),(5,7,9)+(9,12,15),(13,16,21)+(1,2,3))=(14,19,24) \\
& \text { FES7 }=\text { Max }((14,19,24)+(9,15,20),(5,7,9)+(3,5,8))=(23,34,44) \\
& \text { FES8 }=(23,34,44)+(1,2,3)=(24,36,47) \\
& \text { FES9 }=(24,36,47)+(4,5,9)=(28,41,56) \\
& \text { FES10 }=(28,41,56)+(3,4,6)=(31,45,62) \\
& \text { FES11 }=\text { Max }((31,45,62)+(2,4,5),(28,41,56)+(5,7,9,12))
\end{aligned}
$$

Selected methods for ranking fuzzy numbers in CPM calculation have proposed by: (1) Choobineh \& Li [8]; (2) Yager [9]; (3) Cheng [10]; (4) Chen \& Sanguansat [11]; and (5) Abbasbandy \& Hajjari [12]. Table 4 , shows the results of this ranking and Fig. 2 compares the results in bar charts. Also, the project total time and critical path for each method are indicated in Table 2 and Fig. 5. 
Table 2. Results of fuzzy ranking by 5 different methods.

\begin{tabular}{ccc}
\hline Fuzzy Ranking Method & Project Critical Path & Total Time (days) \\
\hline Choobineh \& Li & $0-3-5-7-8-9-10-11$ & 49.9 \\
\hline Yager & $0-3-5-7-8-9-10-11$ & 43.66 \\
\hline Cheng & $0-3-5-7-8-9-11$ & 53.86 \\
\hline Chen \& Sanguansat & $0-3-5-7-8-9-10-11$ & 46.91 \\
\hline Abbasbandy \& Hajjari & $0-3-5-7-8-9-10-11$ & 47.96 \\
\hline
\end{tabular}

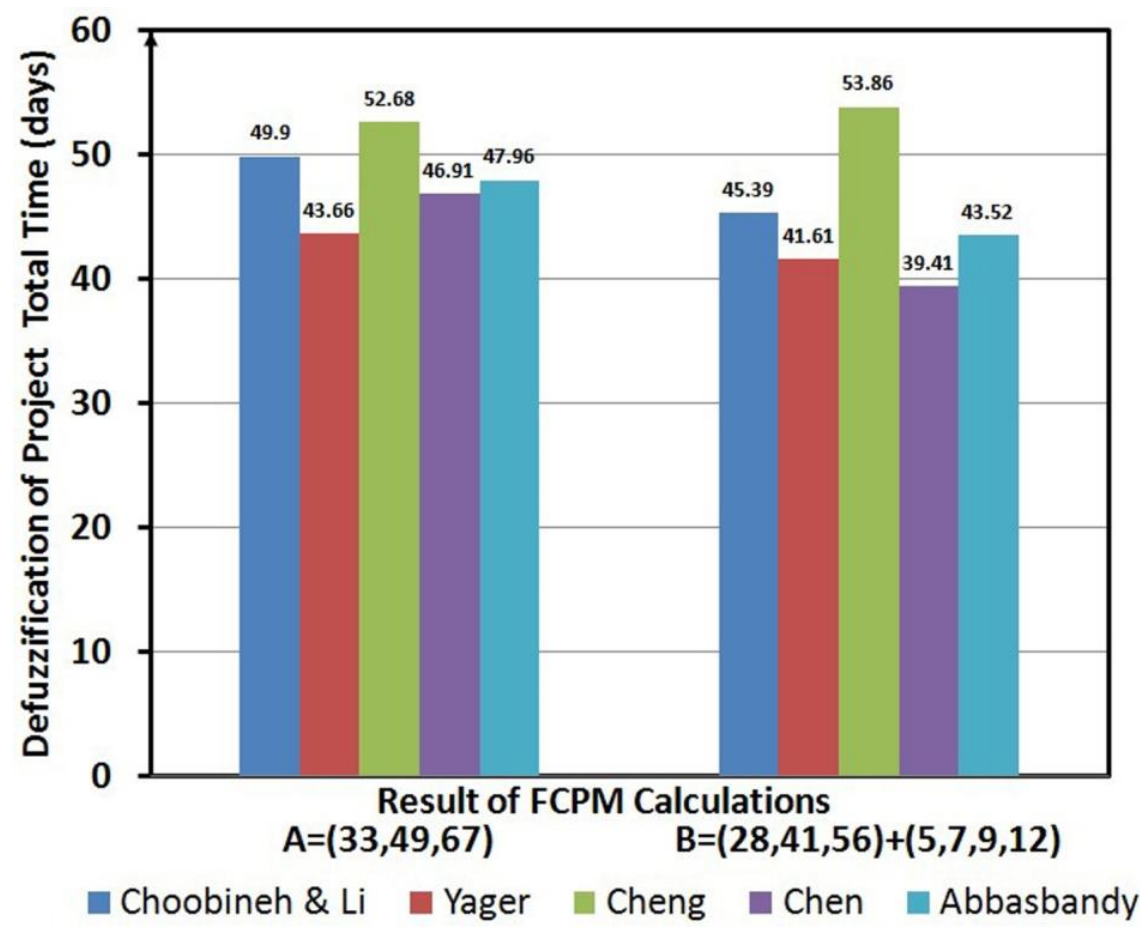

Fig. 5. Results of project time calculation by various fuzzy ranking methods.

\section{Literature Review on Fuzzy Critical Path Method}

Several methods have been proposed for finding the fuzzy critical path over the past years. The main common topic in all of these methods is converting the classic time of project activities to fuzzy numbers for schedule calculation. For the reason that CPM calculation needs to compare the time of activities to determining critical path, a ranking of fuzzy numbers is necessary. So fuzzy numbers ranking is the most important factor in these methods.

For the first time, Chanas and Kamburowski [13] introduced the preliminary concept of FCPM in 1981. They presented the time of project activities by fuzzy set in the time space. Their method provides more direct processing verbally expressed opinions of experts. The significant problem not quite solved in their method was the question of deriving membership functions for activity duration times.

Gazdik [14] used algebraic operators to estimate the time of project activities and project critical path in 1983. Kaufman and Gupta [15] proposed the critical path method in which activity times was represented by fuzzy numbers in 1988. kaufman was one of the great fuzzy logic researchers. He and Aluja had reviewed many types of research about fuzzy logic before. After passing away of Kaufmann, Aluja published the result of their researches [16].

Mc Cahon and Lee [17] presented a new methodology to calculate the fuzzy completion time in 1988. Nasution [18] proposed how to compute total floats and find critical paths in a project network by the fuzzy approach in 1994. Also, Chang et al. [19] presented a methodology to calculate the fuzzy completion project time in 1995 and Lorterapong and Moselhi [20] proposed an extension of fuzzy schedule networks in 1996. Yao and Lin [21] proposed a method for ranking fuzzy numbers without the need for any 
assumptions and have used both positive and negative values to define ordering which then is applied to CPM in 2000.

Chanas and Zielinski [22] presented an approach to the critical concept in a network with fuzzy activity times in 2001. Their approach was devoid of faults which were characteristic for the definitions of fuzzy criticality proposed till 2001 and also Kuchta presented another method to determine fuzzy critical paths and critical activities in this year.

Blue et al. [23] presented a taxonomy of fuzzy graphs that treated fuzziness in vertex existence, edge connectivity and edge weight in 2002. Within that framework, they formulated some standard graphtheoretic problems (shortest paths and minimum cut) for fuzzy graphs using a unified approach distinguished by its uniform application of guiding principles such as the construction of membership grades via the ranking of fuzzy numbers, the preservation of membership grade normalization, and the collapsing of fuzzy sets of graphs into fuzzy graphs and Finally as a result of their research they provided an algorithm solution for fuzzy critical path method.

Yao [24] presented a new approach to implementing a fuzzy CPM for activity networks based on statistical confidence interval estimates and a ranking method for level $(1-\alpha)$ fuzzy numbers in 2003. The focus of his study was to introduce an approach that combined fuzzy mathematics with statistics that includes the signed-distance ranking of level $(1-\alpha)$ fuzzy numbers, derived from $(1-\alpha) \times 100 \%$ confidence-interval estimates. Dubios et al [25] extended the fuzzy arithmetic operational model to compute the latest starting time of each activity in project's network in 2003. Liang and Han [26] presented an algorithm to perform fuzzy critical path analysis for project network problem in 2004.

Oliveros and Robinson [27] presented another method to calculate fuzzy critical paths and critical activities and activity delays in 2005 and also Zielinski [28] extended some results for interval numbers to the fuzzy case for determining the possibility distributions to describe latest starting time of activities in 2006. Also, Han et al [29] used fuzzy critical path method to optimize the airport's cargo ground operation systems in this year. They used this method to tackle the problem in fuzzy airport's ground operation decision makers.

Chen [30] proposed an approach based on the extension principle and linear programming (LP) formulation to critical path analysis in networks with fuzzy activity durations in 2007. Also, Chen and Hsueh [31] presented another simple approach to solving the CPM problems in 2008. They used fuzzy activity times according to linear programming formulation and fuzzy number ordering (ranking) method that was more realistic than crisp one which solved by using the conventional streamlined LP solution approaches. Their obtained fuzzy critical path was assured to be the most critical one from the viewpoint of Yager.

Yakhchali and Ghodsypour [32] introduced the problems of determining possible values of earliest and latest starting times of an activity in networks with minimal time lags and imprecise durations that are represented by means of the interval of fuzzy numbers in 2010. Also, Kumar and Kaur [33] proposed a new method for fuzzy critical analysis in project networks with a new representation of triangular fuzzy numbers in this year. Sathish and Ganesan [34] proposed a new approach based on fuzzy critical path calculation in 2012. They used fuzzy arithmetic and the fuzzy ranking method to determine the fuzzy critical path of the project network without converting the fuzzy activity times to classical numbers and compared their method with other methods.

Rao and Ravi Shankar [35] proposed a new method of fuzzy critical path analysis based on the centroid of centroids of fuzzy numbers in 2013. In their method, durations of activities were considered to be positive trapezoidal fuzzy numbers and a new subtraction operation was proposed to find the fuzzy latest times in the project network. In Continues, Morovatdar et al [36] proposed a new algorithm in this year. Their algorithm instead of asserting a path as critical or non-critical, calculated critically degrees of all project paths along with all project activities. Unlike the existing algorithms up to that year, their proposed algorithm first distinguishes all possibly critical paths of the project and then assigns critically degrees to them determine total project time.

Elizabeth and Sujatha [37] proposed few indices and developed the new algorithms based on them to identify the critical path in a fuzzy environment of project network in 2015. Finally, Kazemi et al. [38] proposed a new method for solving CPM problems by using the expected duration optimization model and the mean-variance model with Liu's definition for random fuzzy variables in 2016. Table 6 summarizes the main historical developments of FCPM ranking from 1981 to 2016. 
Table 3. The Main historical developments and applications of Fuzzy CPM from 1981 to 2016.

\begin{tabular}{|c|c|}
\hline Researchers/Year & Approach of Proposed Method/Events \\
\hline $\begin{array}{l}\text { Chanas \& Kamburowski, } \\
\text { 1981)[13] }\end{array}$ & $\begin{array}{l}\text { Presenting the time of project activities in the form of fuzzy set in the time } \\
\text { space. }\end{array}$ \\
\hline (Gazdik, 1983)[14] & Using algebraic operators to estimate the time of project activities. \\
\hline Kaufman \& Gupta (1988)[15] & $\begin{array}{l}\text { Proposing the CPM in which activity times was represented by fuzzy } \\
\text { numbers. }\end{array}$ \\
\hline (McCahon \& Lee, 1988)[16] & Presenting a new methodology to calculate the fuzzy completion time. \\
\hline (Nasution, 1994) [17] & $\begin{array}{l}\text { Proposed how to compute total floats and find critical paths in a project } \\
\text { network. }\end{array}$ \\
\hline (Chang et al.,1995)[18] & Presenting a methodology to calculate the fuzzy completion project time. \\
\hline $\begin{array}{l}\text { (Loterapong \& Moslehi, 1996) } \\
\text { [19] }\end{array}$ & An extension of fuzzy schedule networks proposed. \\
\hline (Yao \& Lin, 2000) [20] & Proposing a new method for ranking fuzzy numbers in CPM calculation. \\
\hline (Chanas \& Zielinski, 2001) [21] & Presenting the critical concept in a network with fuzzy activity times. \\
\hline (Kuchta, 2001) [22] & Presenting another method to obtain fuzzy critical paths and critical activities. \\
\hline (Blue et al., 2002) [23] & Providing an algorithm solution for fuzzy critical path method. \\
\hline (Yao \& Lin, 2003) [24] & $\begin{array}{l}\text { Presenting a new approach based on statistical confidence interval estimates } \\
\text { and a ranking method for level }(1-\alpha) \text { fuzzy numbers. The focus of his study } \\
\text { was to introduce an approach that combined fuzzy mathematics with } \\
\text { statistics that includes the signed-distance ranking of level }(1-\alpha) \text { fuzzy } \\
\text { numbers, derived from }(1-\alpha) \times 100 \% \text { confidence interval estimates. }\end{array}$ \\
\hline (Dubios et al., 2003)[25] & $\begin{array}{l}\text { Extending the fuzzy arithmetic operational model to compute the latest } \\
\text { starting time of each activity in a project network. }\end{array}$ \\
\hline (Liang \& Han, 2004)[26] & $\begin{array}{l}\text { presenting an algorithm to perform fuzzy critical path analysis for project } \\
\text { network }\end{array}$ \\
\hline $\begin{array}{l}\text { (Oliveros \& Robinson, } \\
\text { 2005)[27] }\end{array}$ & Calculation of fuzzy critical paths and critical activities and activity delays. \\
\hline Zielinski (2005)[28] & $\begin{array}{l}\text { Extending some results for interval numbers to the fuzzy case for } \\
\text { determining the possibility distributions describing latest starting time for } \\
\text { activities. }\end{array}$ \\
\hline (Han et al., 2006)[29] & $\begin{array}{l}\text { Using Fuzzy critical path method to optimize the airport's cargo ground } \\
\text { operation systems. }\end{array}$ \\
\hline (Chen et al., 2007)[30] & $\begin{array}{l}\text { Proposing a new approach based on the extension of linear programming } \\
\text { (LP). }\end{array}$ \\
\hline$($ chen, 2009)[31] & Analyzing fuzzy risk based on ranking generalized fuzzy numbers. \\
\hline $\begin{array}{l}\text { (Yakhchali \& Ghodsypour, } \\
\text { 2010) [32] }\end{array}$ & $\begin{array}{l}\text { Introducing the problems of determining possible values of earliest and latest } \\
\text { starting times of a project activity by means of the interval of fuzzy numbers. }\end{array}$ \\
\hline (Kumar \& Kaur, 2010) [33] & $\begin{array}{l}\text { Proposing a new method with a new representation of triangular fuzzy } \\
\text { numbers. }\end{array}$ \\
\hline (sathish \& Ganessan, 2012)[34] & Proposing a new approach based on fuzzy critical path calculation. \\
\hline $\begin{array}{l}\text { (Rao \& Ravi Shankar, 2013) } \\
\text { [35] }\end{array}$ & $\begin{array}{l}\text { Proposing another method based on the centroid of centroids of fuzzy } \\
\text { numbers. }\end{array}$ \\
\hline (Morovatdar et al., 2013)[36] & $\begin{array}{l}\text { Proposing an algorithm that first distinguished all possibly critical paths and } \\
\text { then assigned critically degrees to them to determine total project time. }\end{array}$ \\
\hline (Elizabet \& Sujatha, 2015)[37] & Proposing few indices to identify the critical path in fuzzy environment. \\
\hline (Kazemi et al. , 2016)[38] & $\begin{array}{l}\text { Proposing a new method for solving CPM problems by using the expected } \\
\text { duration optimization model and the mean-variance model with Liu's } \\
\text { definition for random fuzzy variables. }\end{array}$ \\
\hline
\end{tabular}

\section{Proposed Model for Managing Project Uncertainties}

As described in the previous sections, both types of project uncertainties should be considered in a comprehensive project scheduling. Consequently, the present study proposes a new model based on possible and probable uncertainty management for achieving this purpose. Figure 6 indicates the diagram of the proposed model. 


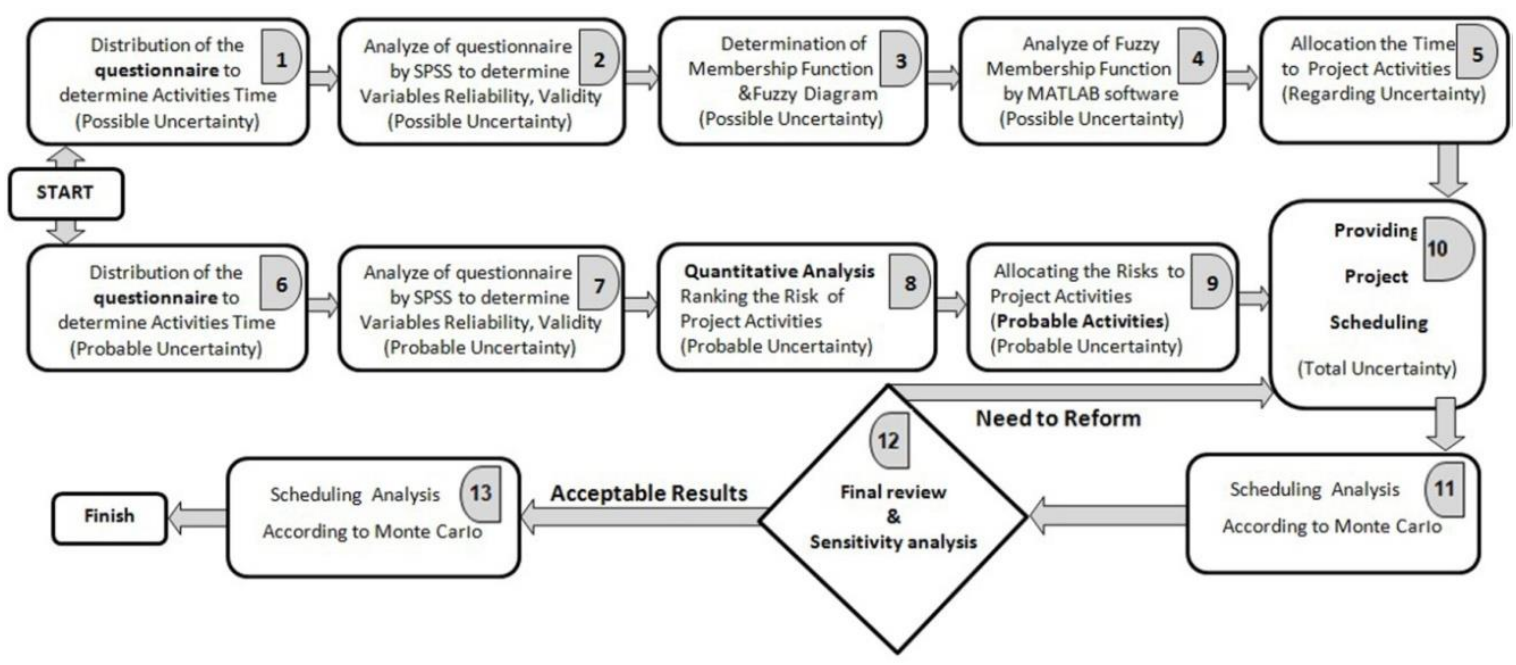

Fig. 6. Diagram of the proposed model.

For implementing the models, at first, two professional questionnaires were distributed between more than 200 experts of a professional team which was selected by the staff of 70 contractors, consultant, and employee companies. The first questionnaire was designed to identify effective factors such as site organization, weather, labor skills and quality of equipment on doing project activities. Then obtained Linguistic variables were translated into mathematical measures. For instance, the questionnaire designed for concreting activity is presented in Table 4. As it can be seen in Table 4, the value of the Linguistic variables is classified into 5 types (Fig. 7).

Table 4. Questionnaire of Fuzzy Expert System Model for concreting activity.

\begin{tabular}{|c|c|c|c|c|}
\hline \multicolumn{5}{|c|}{ Please determine the effect of each factor in the time of Activity } \\
\hline \multicolumn{5}{|c|}{ S01- Concrete Providing Method (Beaching Plant, Concrete Machine, ...) } \\
\hline Very Poor $\square$ & Poor $\square$ & Medium $\square$ & High $\square$ & $\mathrm{h} \square$ \\
\hline \multicolumn{5}{|c|}{ S02- Co-Ownership of Project Supervisions for issuance of Work Permit } \\
\hline Very Poor $\square$ & Poor $\square$ & Med & 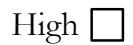 & Very High $\square$ \\
\hline \multicolumn{5}{|c|}{ S03- Co-Ownership of Concrete Laboratory for Sampling } \\
\hline Very Poor $\square$ & Poor $\square$ & & High $\square$ & $\square$ \\
\hline \multicolumn{5}{|c|}{ ate. Warm, Very Warm) } \\
\hline Very Poor $\square$ & Poor $\square$ & Medium $\square$ & & \\
\hline \multicolumn{5}{|c|}{ S05- HSE (Health-Safety-Environments) Criteria } \\
\hline $\mathrm{Ve}$ & & Medium $\square$ & High [ & $\operatorname{igh} \square$ \\
\hline \multicolumn{5}{|l|}{ S06- The Geometr } \\
\hline Very Poor $\square$ & Poor $\square$ & Medium $\square$ & High $\square$ & \\
\hline \multicolumn{5}{|c|}{ Cement Type 3, Cement Type $5, \ldots$ ) } \\
\hline & & Medium [ & High & \\
\hline
\end{tabular}

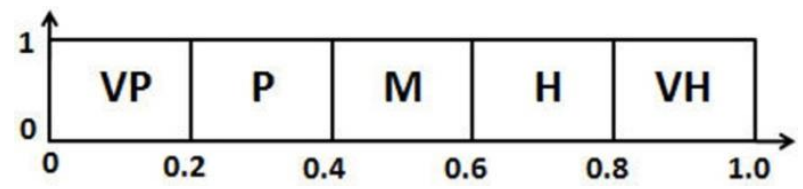

Fig. 7. Categorization of membership functions.

As in Table 5, a large number of factors are considered to estimate the time of concreting activity. To examine the reliability of the questionnaire, data analysis was done by SPSS. According to SPPS analysis, the Cronbach's alpha (Reliability Index) was 0.388, while it should be greater than 0.7. 
Table 5. Results of reliability index calculated by SPSS.

\begin{tabular}{clccc}
\hline $\begin{array}{c}\text { Factor } \\
\text { Code }\end{array}$ & \multicolumn{1}{c}{ Factor Description } & $\begin{array}{c}\text { Scale Mean if } \\
\text { Item Deleted }\end{array}$ & $\begin{array}{c}\text { Scale Variance if } \\
\text { Item Deleted }\end{array}$ & $\begin{array}{c}\text { Total } \\
\text { Correlation }\end{array}$ \\
\hline S01 & Concrete Providing Method & 13.00 & 7.926 & 0.613 \\
S02 & Co-Ownership of Project Supervisions & 14.14 & 12.423 & -0.200 \\
S03 & Co-Ownership of Concrete Laboratory & 14.61 & 11.507 & 0.114 \\
S04 & Climatic Condition & 12.29 & 7.545 & 0.798 \\
S05 & HSE Criteria & 12.68 & 10.078 & 0.242 \\
S06 & The Geometry of the Structure & 14.29 & 12.063 & -0.105 \\
S07 & Type of Cement Used in Concrete & 14.14 & 8.868 & 0.186 \\
\hline
\end{tabular}

The results show that factors 2, 3, 6 and 7 do not have an effective influence on the timing of concreting activity. So these factors were eliminated and calculations were repeated. In the new analysis, the index rose up to 0.854 which is desirable. So the main factors of concreting activity are concrete providing method, climatic conditions, and HSE criteria. In the next step, the second questionnaire which relates to estimating activity durations was distributed among team members. After summing up the results of the first and second questionnaires, obtained results were examined by an expert team that composed of 8 expert project managers (With more than 25 years of experience) to determine its content validity. Then, according to satisfactory results, the structural validity of survey questionnaires was evaluated by Factor Analysis method. According to the KMO index, the acceptable construct validity of research was approved. The results of the analysis are summarized in Table 6.

Table 6. The results of factor analysis method (KMO and Bartlett's Test).

\begin{tabular}{ccc}
\hline Kaiser-Meyer-Olkin Measure of Sampling Adequacy & $\mathbf{0 . 6 3 5}$ \\
\hline & Approx. Chi-Square & 49.534 \\
Bartlett's Test of Sphericity & df & 3 \\
& Sig. & 0.000 \\
\hline
\end{tabular}

Also, the results of the total variance of analysis explained that these three factors are not reducible to the number of agent-less (Table 7). According to the results obtained from computing of the Pearson Correlation coefficient, the correlation between these factors is also desirable. Table 8 indicates related results.

Table 7. The results of total variance of analysis.

\begin{tabular}{cccc}
\hline \multirow{2}{*}{ Component } & \multicolumn{3}{c}{ Total Variance Explained } \\
& Total & \% of Variance & Cumulative \% \\
\hline 1 & 1.335 & 38.14 & 38.14 \\
2 & 1.058 & 30.23 & 68.37 \\
3 & 1.107 & 31.63 & 100 \\
\hline
\end{tabular}

Table 8. The results of correlation between concreting activity's efficient factors.

\begin{tabular}{ccccc}
\hline \multicolumn{2}{c}{ Correlation Results } & S01 & S04 & S05 \\
\hline \multirow{2}{*}{ S01 } & Pearson Correlation & 1 & 0.89 & 0.57 \\
& Sig. (2-tailed) & & 0.000 & 0.001 \\
\hline \multirow{2}{*}{ S04 } & Pearson Correlation & 0.89 & 1 & 0.52 \\
& Sig. (2-tailed) & 0.000 & & 0.005 \\
\hline \multirow{2}{*}{ S05 } & Pearson Correlation & 0.57 & 0.52 & 1 \\
& Sig. (2-tailed) & 0.001 & 0.005 & \\
\hline
\end{tabular}

In Later stages of the proposed model, membership functions of these factors were drawn according to the second questionnaire. The second questionnaire is in regard to a time estimation of the experiences of the professional team. In this research, Fuzzy diagrams were of triangular and trapezoidal types. In the present example, Figures 8 to 10 indicate the fuzzy membership functions of concreting activity factors. 
These diagrams are considered as the input of analysis.

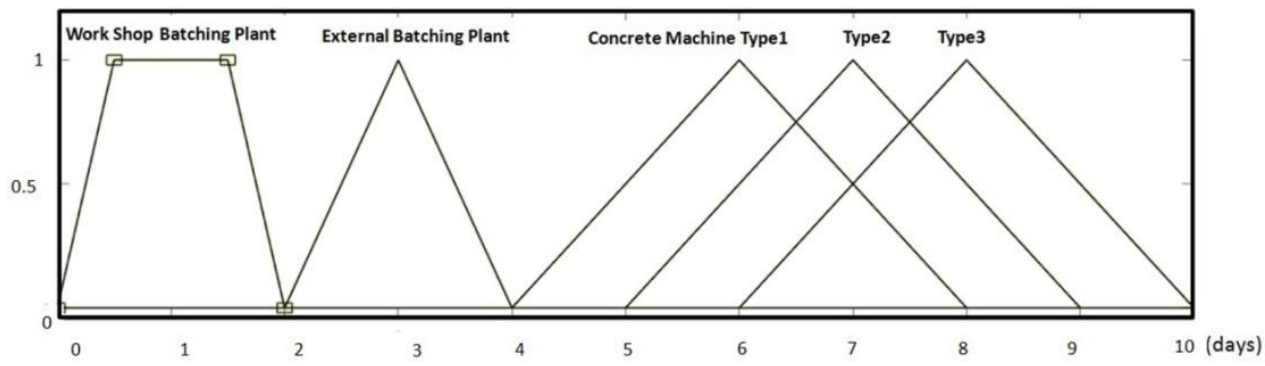

Fig. 8. Fuzzy Membership Function of Concrete Providing Method Factor.

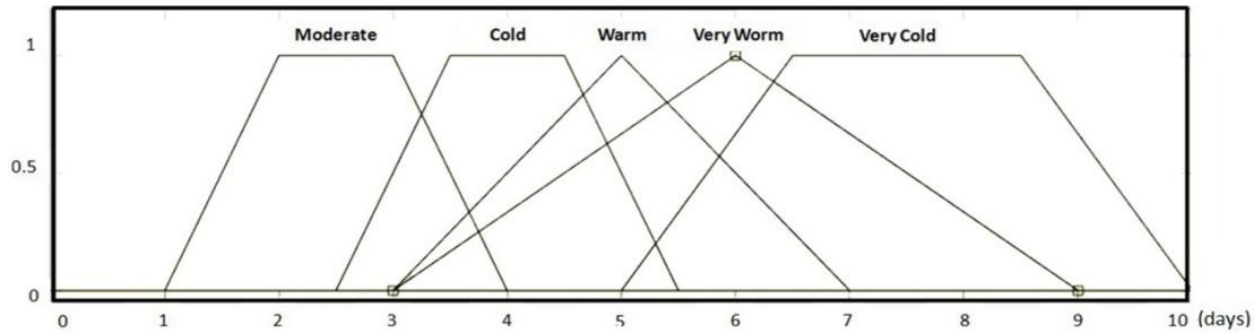

Fig. 9. Fuzzy Membership Function of Climatic Conditions Factor.

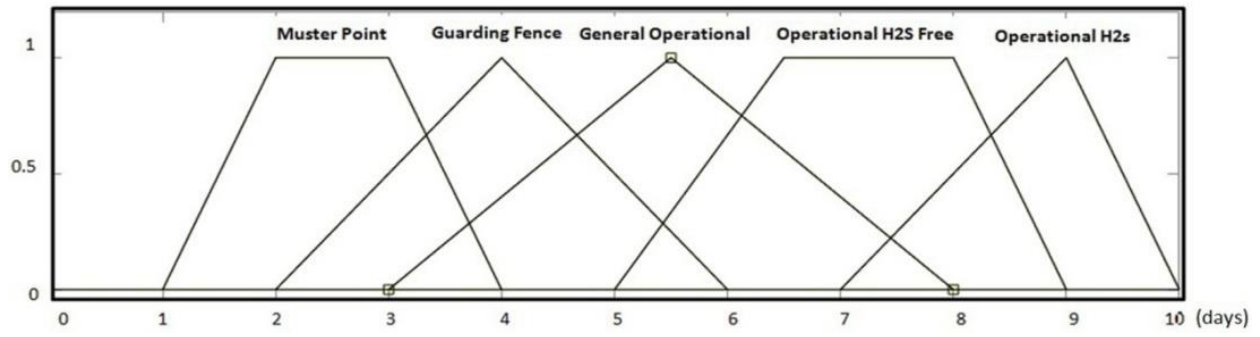

Fig. 10. Fuzzy Membership Function of HSE Criteria Factor.

Then, the results of the previous step were analyzed in Fuzzy Toolbox of MATLAB. This toolbox follows a Rule Base System. Analysis of model is presented in Fig. 11. As it could be seen in this figure, inputs are processed by a smart and rule base system.

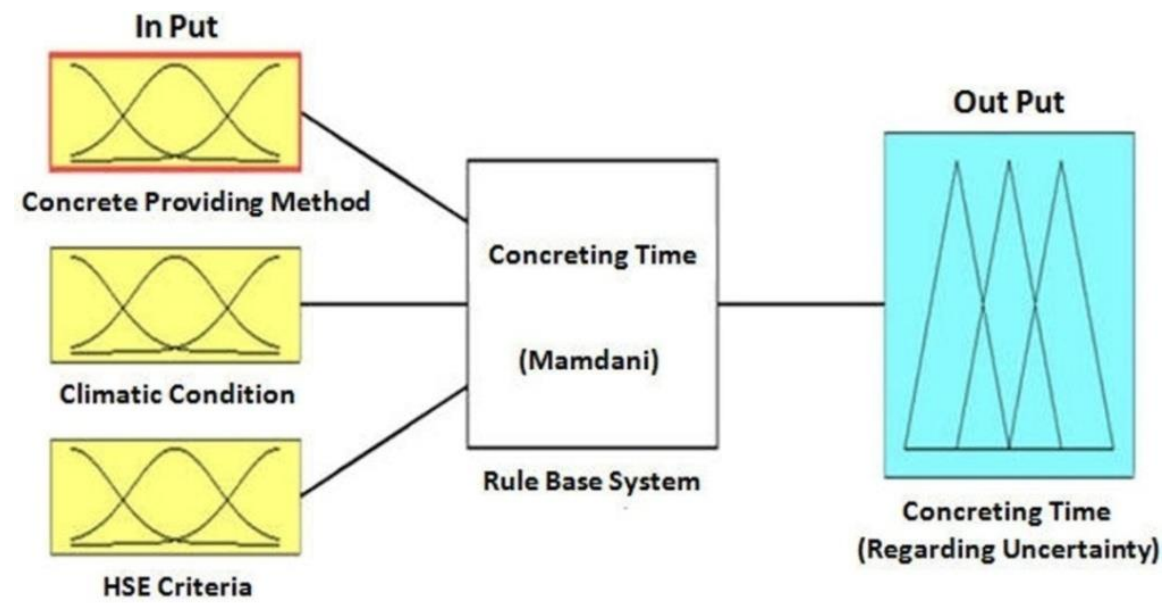

Fig. 11. Diagram of proposed model analysis. 
"IF ... Then ..." rules were set by the expert team in Rule Base system. For example, for these 3 factors, 125 operating modes may occur. Three states of these rules are observed in Table 9.

Table 9. An example of Rules that are used in the Rule Base system.

\begin{tabular}{cl}
\hline Rule No & \multicolumn{1}{c}{ The Rule } \\
\hline Rule $\mathbf{1}$ & $\begin{array}{l}\text { If concrete providing method is Batching plant and climatic conditions moderate and } \\
\text { HSE zone is muster point then the time of concreting is very short. }\end{array}$ \\
\hline Rule 2 & $\begin{array}{l}\text { If concrete providing method is concrete machine type } 1 \text { and the climatic condition is } \\
\text { cold and HSE zone is with H2S penetration then the time of concreting is very long. }\end{array}$ \\
\hline Rule 3 & $\begin{array}{l}\text { If concrete providing method is out of site Batching and the climatic condition is warm } \\
\text { and HSE zone is muster point then the time of concreting is very short. }\end{array}$ \\
\hline
\end{tabular}

After analysis, the duration of activities under uncertainty and fuzzy approach can be achieved. For example, this time for the above-mentioned activity (concreting) will be 8.5 days for each 200 cubic meters of concrete (Fig. 12).

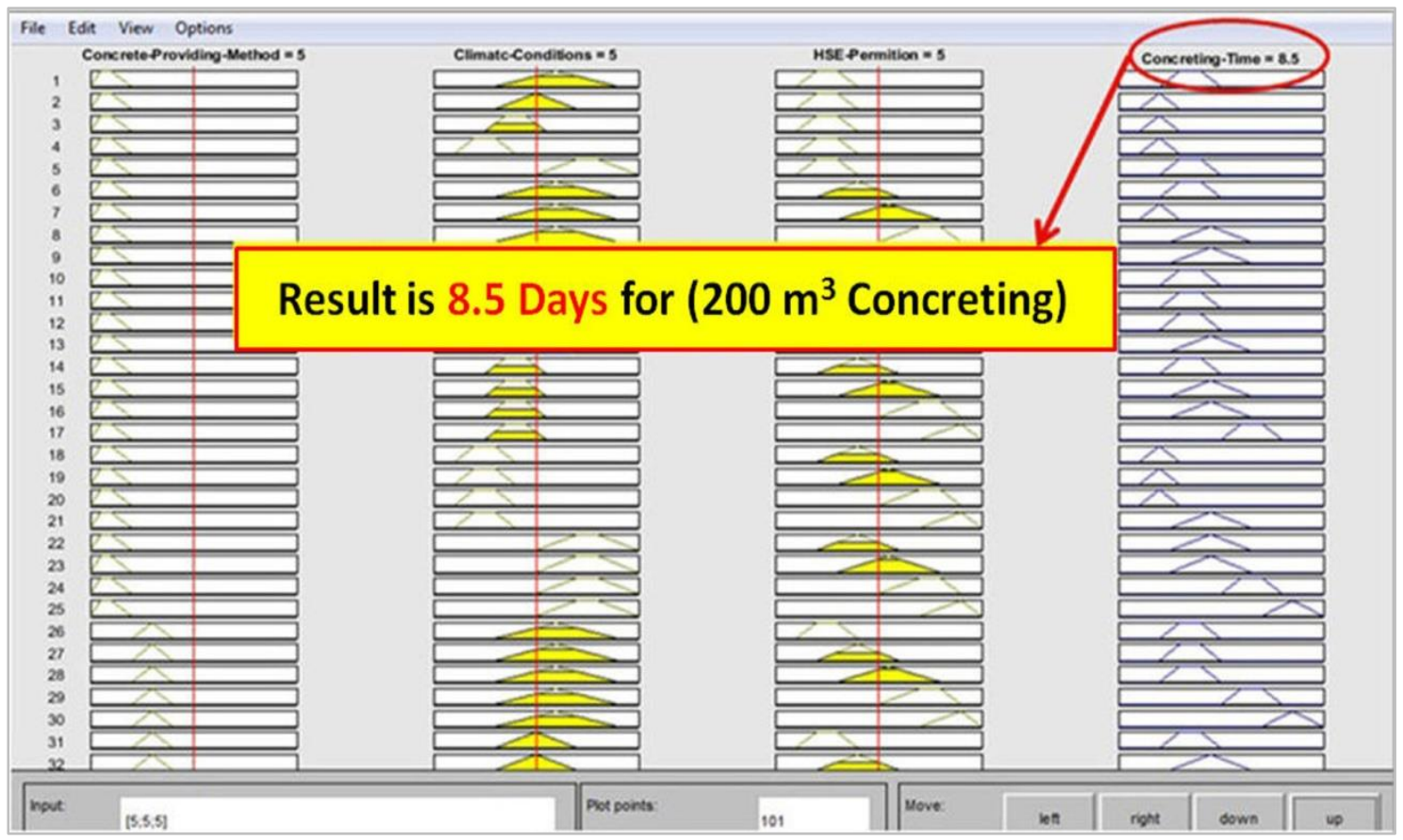

Fig. 12. Pictorial view of analysis output.

After calculating the time of all activities according to this method, project schedule was designed under possible uncertainty. So in the next stage, in order to regard probable uncertainty, we need to add project risks to designed project schedule. The probable uncertainty in the model could be considered by two methods. The first method recognizes the risks in terms of completed questionnaires and would handle other stages of project risk management based on the obtained results. In the second method, the results of previous studies through similar statistical data derived from similar projects would be utilized. Since the application of risk management in gas refineries goes back to many years ago, the second method is a high priority. Thus, this study attempts to review the literature of risk management in construction projects of Iranian gas refineries which have been completed from 2010 to 2016 (Table. 10) [39-48]. These studies were classified as a database of construction project risks in gas refineries (Table. 11). In the following stages, expert team allocates the selected risks to each activity of project as a probable activity. 
Table 10. The main historical researchers of risk management in Iranian gas refineries from 2010 to 2016.

\begin{tabular}{cl}
\hline Researchers/Year & \multicolumn{1}{c}{ Approach of Research } \\
\hline $\begin{array}{c}\text { (Jalaee \& Mahdaviparsa, 2010) } \\
\text { [39] }\end{array}$ & $\begin{array}{l}\text { They studied risk management in Iranian construction projects such as gas } \\
\text { refineries as a survey study. }\end{array}$ \\
\hline $\begin{array}{c}\text { (Soltani et al., 2011) [40] } \\
\text { (Hamzei \& Alamtabriz, 2012) }\end{array}$ & $\begin{array}{l}\text { They reviewed the risks of projects in Shiraz refinery by FMEA method. } \\
\text { projects. Also, they reviewed the risks in refinery projects. }\end{array}$ \\
\hline $\begin{array}{c}\text { (Moharramnejad \& } \\
\text { Amanatyazdi, 2013) [42] }\end{array}$ & They reviewed risk management in Iranian oil and gas Companies. \\
\hline (Bordbar et al., 2013) [43] & $\begin{array}{l}\text { They reviewed the Identification and allocation of risks in construction projects } \\
\text { of Sarkhoon \& Gheshm gas refinery. }\end{array}$ \\
\hline (Ardeshir et al., 2014) [44] & $\begin{array}{l}\text { They reviewed Safety Assessment in refinery and other construction projects } \\
\text { based on Analytic Hierarchy Process. }\end{array}$ \\
\hline (Doosti et al., 2014) [45] & They reviewed the risk management in the construction of gas refineries. \\
\hline (Najafi et al., 2015) [47] & They reviewed risk quantification in complex and fast projects. \\
\hline (Ghasemi et al., 2015) [48] & $\begin{array}{l}\text { They presented a new method for scrutiny the Insurable Risk in Iranian gas } \\
\text { refineries by FMEA. }\end{array}$ \\
\hline
\end{tabular}

Table 11. Sample database of construction project risk index (RPN) in gas refineries.

\begin{tabular}{|ccc|ccc|}
\hline No & Risk Description & RPN & No & Risk Description & RPN \\
\hline 1 & Falling from Crane & 600 & 11 & Political and economic sanctions & 280 \\
\hline 2 & Falling from scaffolding & 570 & 12 & Fluctuations in steel prices \& rebar & 252 \\
\hline 3 & Falling from Structure & 565 & 13 & Price eccentric of contractors & 216 \\
\hline 4 & Falling from Openings & 524 & 14 & Lack of necessary infrastructure & 210 \\
\hline 5 & Work injury due to Falling objects & 424 & 15 & Fluctuations in the price of cement & 150 \\
\hline 6 & Damage due to Excavation & 392 & 16 & Welding - damage to the eyes & 120 \\
\hline 7 & Fire - Refinery Equipment Damage & 390 & 17 & Fire - damage to persons & 120 \\
\hline 8 & burns from an electric shock & 383 & 18 & Clash with underground pipes & 120 \\
\hline 9 & Explosion & 373 & 19 & Work injury due to Cutting & 105 \\
\hline 10 & Toxicity of chemical spill & 288 & 20 & Damage caused by animals $/$ insects & 96 \\
\hline
\end{tabular}

Also, there are two procedures for allocating risks to project activities in the proposed model of the present study. The first procedure is allocating the risks to each activity as a probable activity and second is allocating probable branches to the intended activities. For example, in a brick veneer activity, the risk of "consequences of fall from the height" with a probability of $5 \%$ is allocated to risk management (Fig. 13).

Also, Risks can be allocated to activities as probable branches. For example, in "plumbing hot and cold water" activity, three probable branches are considered. These branches are: (1) "test is ok" with the probability of $70 \%$; (2) "Minor problem that could be repaired by technicians" with the probability of $20 \%$; (3) "A major problem that need to Re-Work" with the probability of 5\% (Fig. 13).

In the final stage of the proposed model, project schedule will be designed based on managing both types of uncertainties. Figure 13 shows a sampling project schedule that designed according to the proposed model of this research that belongs to a sample project whit the title of SGPC Pardis staff pension construction project. Then the provided schedule is analyzed on the basis of Monte Carlo method. This analysis was done by the Risk Analysis software. Primavera Risk Analysis is a full lifecycle risk analytics solution that provides a comprehensive means of determining confidence levels for project success with quick and easy techniques for determining contingency and risk response plans. If the project schedule has a confidence level of 95 percent, it will be accepted; otherwise, it should be rechecked to experience possible modifications. Figure 14 presents the obtained results of proposed model in SGPC Pardis staff pension project. In this figure, high risks and low risks are shown by red and green colors respectively. 


\begin{tabular}{|c|c|c|c|c|c|c|}
\hline ID & Description & $\begin{array}{l}\text { Remaining } \\
\text { Duration }\end{array}$ & Start & Finish & 2015 & 2016 \\
\hline 0001 & Construction of SGPC Pension & 424 & $02,01 / 15$ & $17 / 08 / 16$ & & \\
\hline 0002 & Start & 0 & $02,01 / 15$ & & & \\
\hline 0004 & Construction Activities & 400 & $02 / 01 / 15$ & $14 / 07 / 16$ & & \\
\hline 0400 & Site preparation & 30 & $02,01 / 15$ & $12 / 02 / 15$ & & \\
\hline 0410 & Brick Veneer & 214 & $13,02 / 15$ & $09 M 2 M 5$ & & \\
\hline 0411 & Brick Veneer - West Part & 40 & $13 / 02 M 5$ & $09 / 04 / 15$ & Erick Ve & \\
\hline 2000 & $\begin{array}{l}\text { The consequences of a fall } \\
\text { from scaffolding }\end{array}$ & 7 & $10,04 / 15$ & $20 / 04 / 15$ & 5 & fall from scaffolding \\
\hline 0412 & Brick Veneer -South Part & 50 & $21 / 04 / 15$ & $29,06 / 15$ & $\begin{array}{r}\text { Brick Ver } \\
\square\end{array}$ & ant \\
\hline 2010 & The consequences of a fall & 7 & $30,06 / 15$ & $08 / 07 / 15$ & & es of a fall \\
\hline 0413 & Brick Veneer - North Part & 50 & $30,06 / 5$ & $07 / 09 / 5$ & & lorth Part \\
\hline 2020 & The consequences of a fall & 7 & $08,09 / 15$ & $16,09 / 15$ & & equences of a fall \\
\hline 0414 & Brick Veneer - Internal Void & 60 & $17,09 / 15$ & $09 / 12 / 15$ & & $\begin{array}{l}\text { heer - Internal Void } \\
17,09 M 5\end{array}$ \\
\hline 0420 & $\begin{array}{l}\text { Complete coverage of plaster } \\
\text { residue levels }\end{array}$ & 120 & $13,02 / 15$ & $30 / 07 / 15$ & & \\
\hline 0430 & Flooring residue levels & 61 & $13,02 / 15$ & $08 / 05 / 15$ & & \\
\hline 0440 & Water insulation & 50 & $20,04 / 15$ & $26,06 / 15$ & & \\
\hline 0450 & $\begin{array}{l}\text { The final phase of the } \\
\text { operation Joinery }\end{array}$ & 250 & $31,07 M 5$ & $14 / 07 / 16$ & & \\
\hline 0005 & $\begin{array}{l}\text { Mechanical enforcement } \\
\text { activities }\end{array}$ & 350 & $13,02 M 5$ & $16,06 / 16$ & & \\
\hline 0510 & $\begin{array}{l}\text { Mechanical installation } \\
\text { channels }\end{array}$ & 95 & $13.02 M 5$ & $25,06 / 15$ & & \\
\hline 0511 & $\begin{array}{l}\text { Construction of the facility } \\
\text { Channels }\end{array}$ & 60 & $13,02 / 15$ & $07 / 05 / 15$ & C & frannels \\
\hline 0512 & Install supports of channels & 30 & $13 / 02 M 5$ & $26 / 03 / 15$ & $\pi$ & \\
\hline 0513 & Install of Channels & 15 & $08,05 M 5$ & $28 / 05 / 15$ & & \\
\hline 0514 & Insulation channels & 20 & $29,05 / 15$ & $25 / 06 / 15$ & $\rightarrow \square$ 29,05M5 & \\
\hline 0520 & $\begin{array}{l}\text { water plumbing and } \\
\text { firefighting project }\end{array}$ & 75 & $31,07 / 15$ & $12 M 1 M 5$ & & \\
\hline 0521 & Hot and cold water plumbing & 60 & $31,07 / 15$ & $22 M 0 M 5$ & & $\begin{array}{l}\text { water plumbing } \\
\text { T } 15\end{array}$ \\
\hline 0522 & plumbing of firefighting & 60 & $31,07 / 5$ & $22 M 0 M 5$ & & $\begin{array}{l}\text { irefighting } \\
7 / 15\end{array}$ \\
\hline 0523 & $\begin{array}{l}\text { Split of discharge pipes } \\
\text { installation }\end{array}$ & 30 & $31,07 / 15$ & $10 / 09 / 15$ & & arge pipes installation \\
\hline 0524 & Plumbing fire test & 15 & $23 M 0 / 15$ & $12 M 1 M 5$ & 162 & ing fire test \\
\hline 0525 & Test hot and cold water plu... & 10 & $23 / 10 / 15$ & $05 / 11 / 5$ & & $\begin{array}{l}\text { ot and cold water plumbing } \\
10 / 15\end{array}$ \\
\hline 2030 & Test is OK & 10 & $06 / 11 / 15$ & $19 / 11 / 15$ & $0 \%$ & $\begin{array}{l}\text { is OK } \\
6 M 1 M 5\end{array}$ \\
\hline 2040 & $\begin{array}{l}\text { Test Not Ok - Repair minor } \\
\text { problems }\end{array}$ & 12 & $06 / 1115$ & $23 M 1 M 5$ & $\%$ & $\begin{array}{l}\text { Not OK - Repair minor problems } \\
111 M 5\end{array}$ \\
\hline 2050 & $\begin{array}{l}\text { Test Not Ok - Need to } \\
\text { Re-Work }\end{array}$ & 20 & $06 / 11 / 5$ & $03 M 2 M 5$ & $5 \%$ & $\begin{array}{l}\text { Not Ok - Need to Re-Work } \\
66 / 11 / 15\end{array}$ \\
\hline 0530 & Sanitary sewer and rainwater & 140 & $04 M 2 M 5$ & $16,06 / 16$ & & \\
\hline 0540 & Installation of sanitary valves & 20 & $18,03 / 16$ & $14 / 04 / 16$ & & \\
\hline 0550 & Installation of Air Conditions & 25 & $29,05 / 15$ & $02 / 07 / 15$ & & \\
\hline 0560 & $\begin{array}{l}\text { Installation of Mechanical } \\
\text { Room }\end{array}$ & 120 & $31,07 / 15$ & $14 / 01 / 16$ & & \\
\hline 0570 & Other mechanical Activites & 50 & $15.01 / 16$ & $24 / 03 / 16$ & & \\
\hline 0006 & Electrical Activities & 380 & $13,02 M 5$ & $28 / 07 / 16$ & & \\
\hline 0610 & $\begin{array}{l}\text { rerequisites of Electrical } \\
\text { Activities }\end{array}$ & 260 & $13 / 02 / 15$ & $11 / 02 / 16$ & & \\
\hline 0620 & $\begin{array}{l}\text { Installation and testing of } \\
\text { Lighting }\end{array}$ & 260 & $31,07 / 15$ & $28,07 M 6$ & & \\
\hline 0007 & Implementation of landscaping & 39 & $24 / 06 / 16$ & $17: 08 M 6$ & & \\
\hline 0009 & Finish & 0 & & $17,08 / 16$ & & \\
\hline
\end{tabular}

Fig. 13. Sampling project schedule that designed according to the proposed model of this research. 

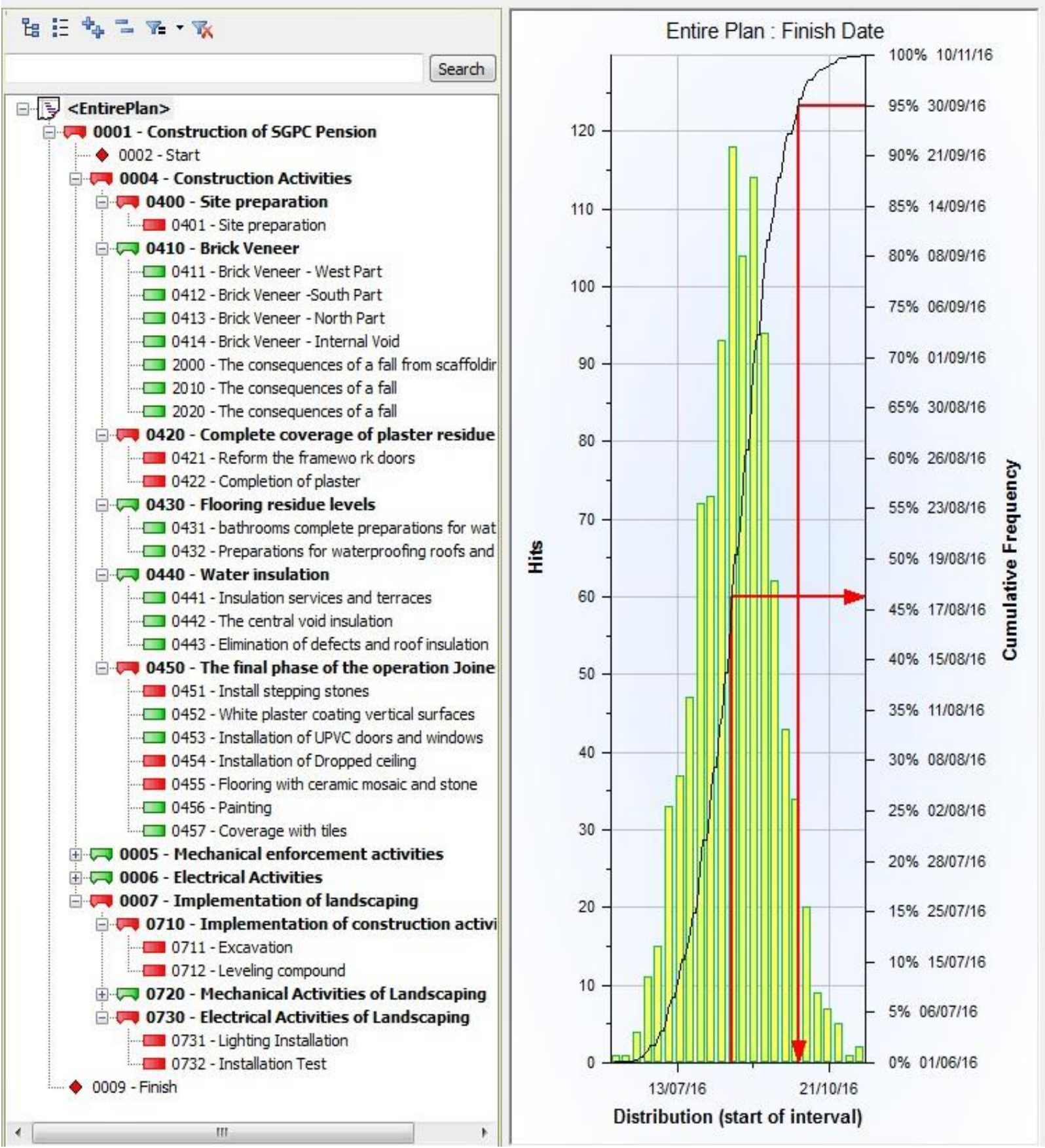

Fig. 14. A sample of results obtained from the proposed model analysis.

\section{Results of Proposed Model Implementation}

The proposed model of the research has been implemented in one gas refinery in the North East of Iran. This gas refinery provides cooking and industrial gas for 5 provinces in the north and east of Iran, including Khorassan, Semnan and, parts of Golestan. The study period was between 2014 and 2016 and the sampling of this study was composed of 30 projects based on Cochran formula [49]. Figure 15 shows the pictorial view of some of these sampling projects and Table 12 mentioned the title of the project that used in research studies. 


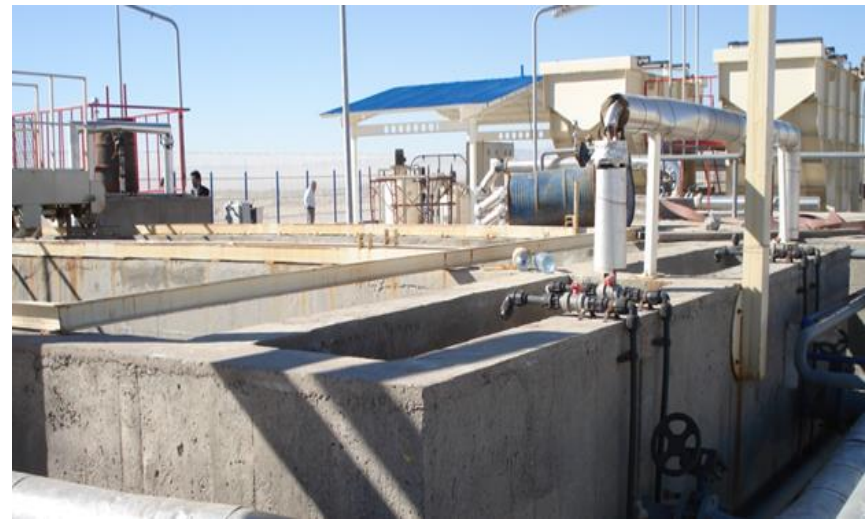

Construction of Oily Water Separator unit

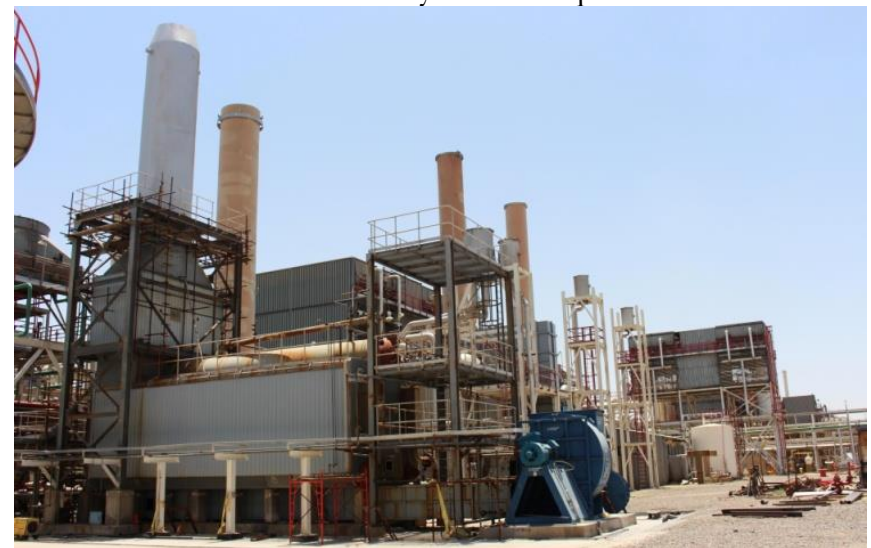

Installation of the seventh boiler of refinery

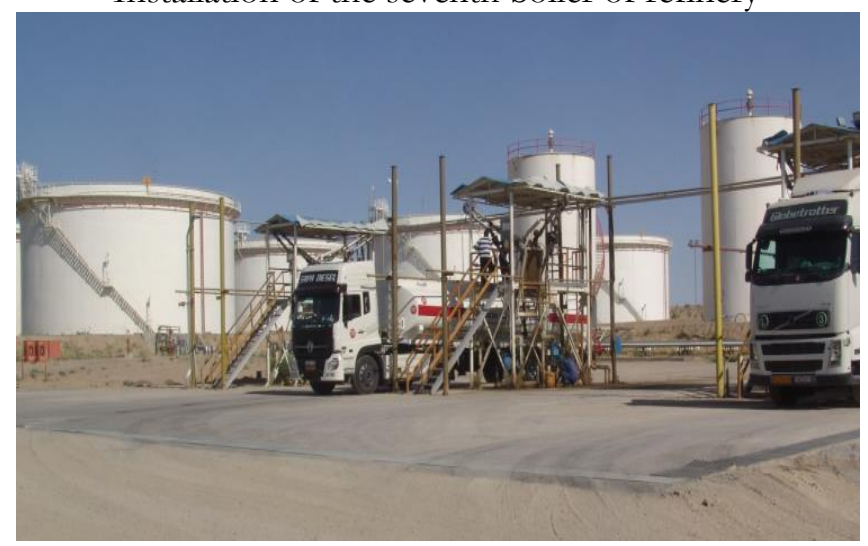

Construction of Loading HC-Condensate Area

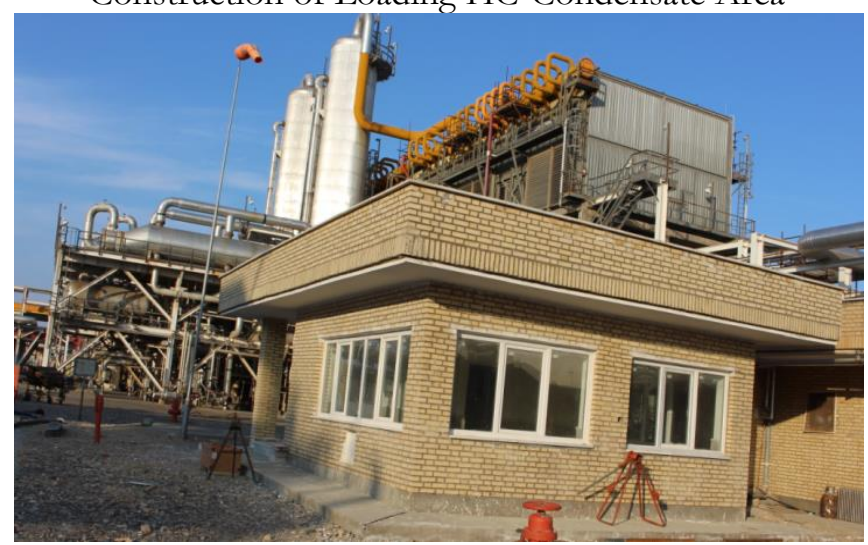

Construction of new senior operator room

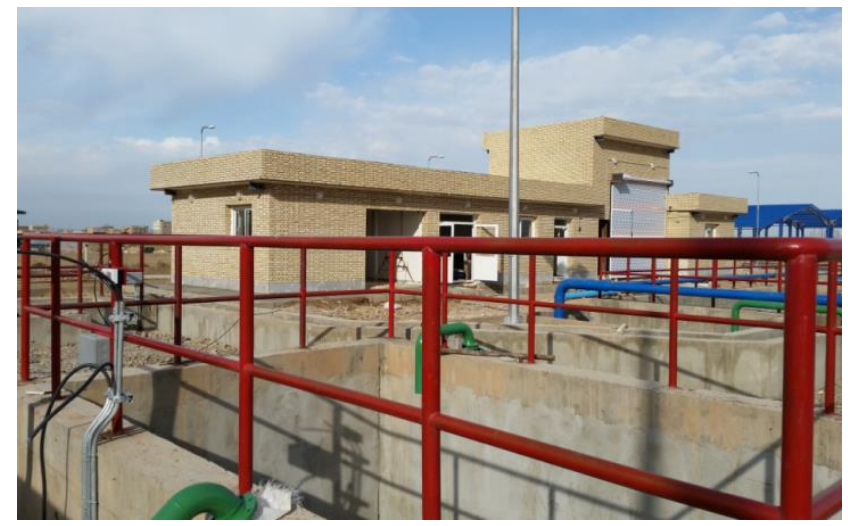

Construction of refinery sewage



Construction of HSE building

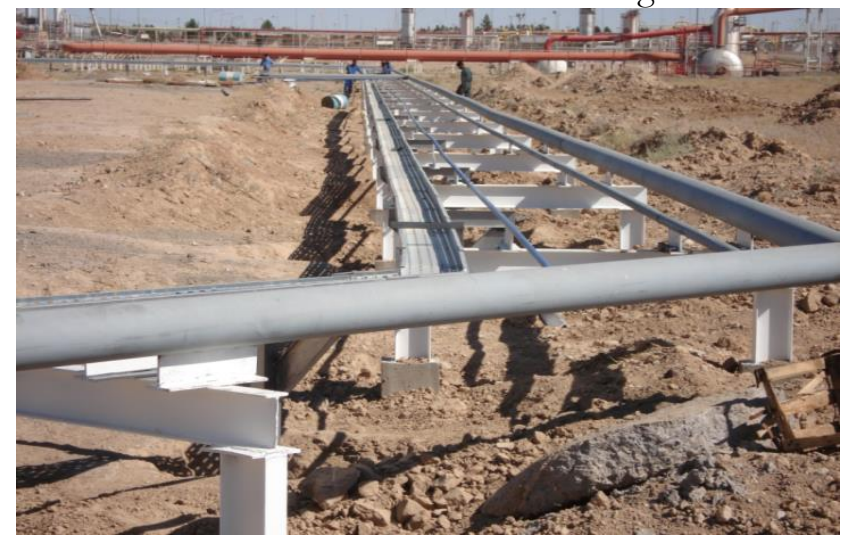

Construction of OWS transmission pipelines

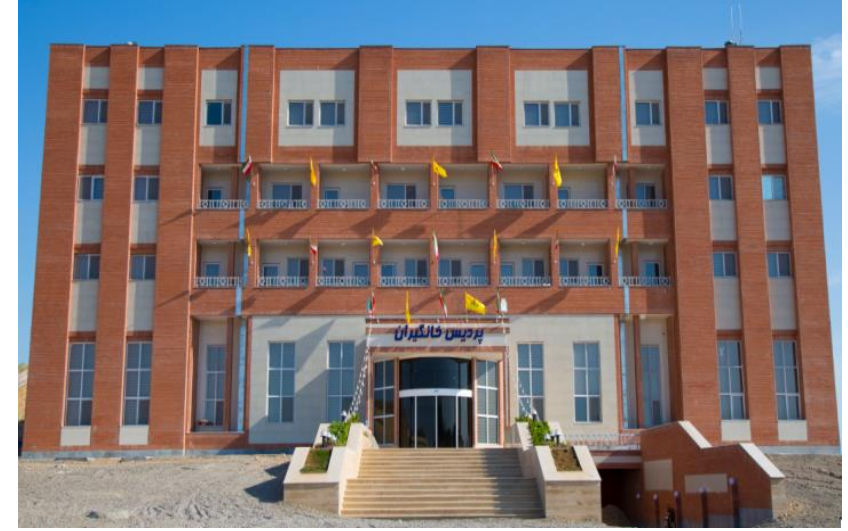

Construction of SGPC Pardis pension

Fig. 15. Pictorial view of some of the sampling projects. 
Table 12. The title of project that used in research studies.

\begin{tabular}{|cl|cl|}
\hline $\begin{array}{c}\text { Project } \\
\text { ID }\end{array}$ & \multicolumn{1}{c|}{ Title of project } & Project & \multicolumn{1}{c|}{ Title of project } \\
\hline P001 & Construction of Pardis staff pension & P016 & Construction of Sculpture Unit Road \\
\hline P002 & Construction of Oily Water Separator & P017 & Construction of Senior Operator Room \\
\hline P003 & Degassing of Granulation Unit & P018 & Construction of HSE Energy Chanel \\
\hline P004 & Construction of Housing center & P019 & Performing P.F Wall in Torshizi Residential \\
\hline P005 & Construction of Ware House Building & P020 & Performing of Pardis Gas line \\
\hline P006 & Movement of Gonbazli sole & P021 & Performing of Pardis Power \& Data line \\
\hline P007 & Extending of Central Restaurant & P022 & Performing of Pardis Waterline \\
\hline P008 & Construction of Sculpture Platform & P023 & Construction of Loading HC-Condens area \\
\hline P009 & Optimization of Shahid Mohajer Pool & P024 & Performing of Pardis Complex Sewage line \\
\hline P010 & Construction of Gas station & P025 & Construction of Contractor Building \\
\hline P011 & Construction of Torshizi Sewage & P026 & Performing of O.W.S Supports \\
\hline P012 & Construction of TPL Fencing & P027 & Installation of the 7th boiler of refinery \\
\hline P013 & Construction of oil Loading Pavement & P028 & Construction of CMF Pipe Line \\
\hline P014 & Construction of Transportation Sole & P029 & Performing of General Civil Maintenance \\
\hline P015 & Performing of Refinery F \& G System & P030 & Restaurant's Cold and Mechanical Room \\
\hline
\end{tabular}

For implementing the proposed model, at first, two professional questionnaires were distributed between a professional team which was selected by the staff of 70 contractors, consultant, and employee companies. The first questionnaire was designed to identify effective factors on doing project activities. Then obtained Linguistic variables were translated into mathematical measures. In the following, obtained information was processed by MATLAB and fuzzy times were dedicated to project activities. In the second phase, risks were added to project as probable activities. Finally, the integrated time of projects activities was analyzed by Monte Carlo method and outputs show that the accuracy of project time calculation was improved about 8 to 24 percent. Fig. 16 indicates the improvement of the mentioned project time estimation.

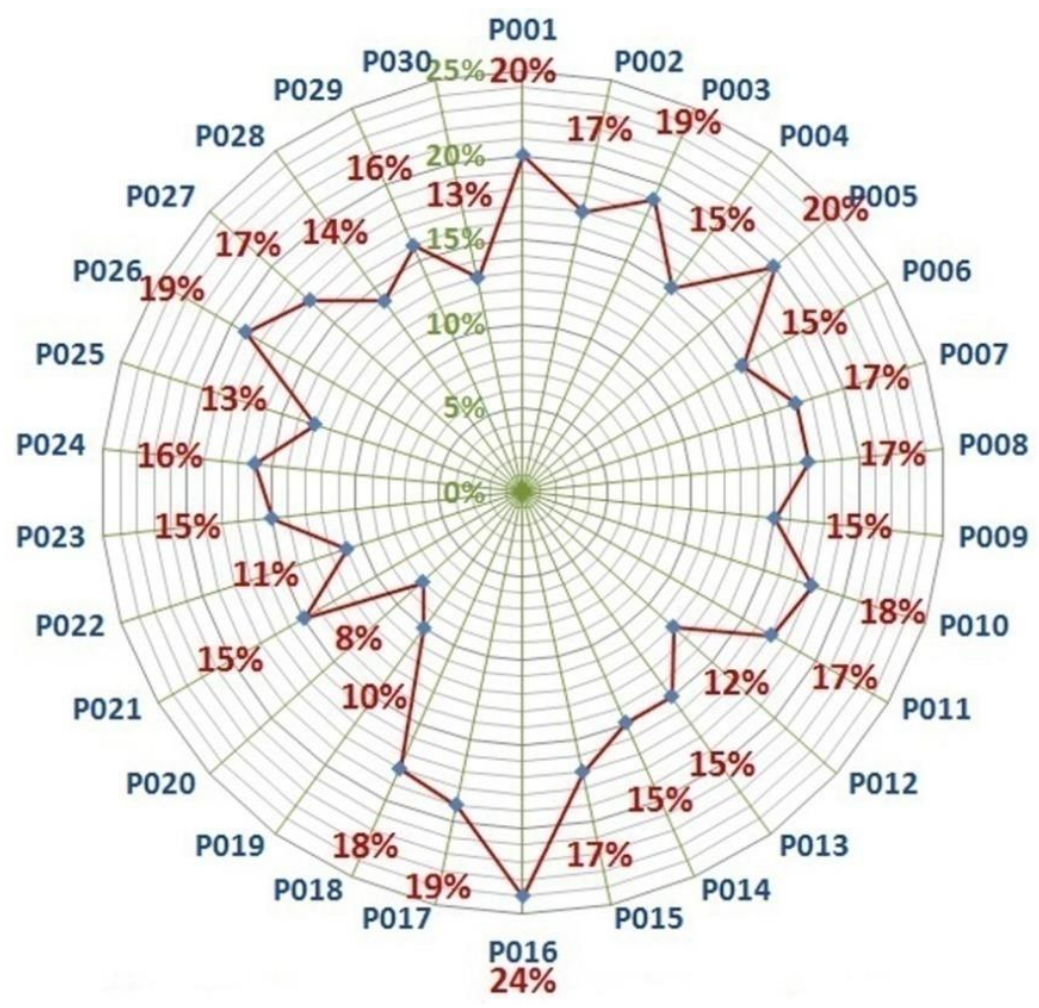

Fig. 16. The rate of improvement in project time estimation by proposed model. 


\section{Conclusion}

This study investigated a new model for comprehensive time estimation in construction projects of the Iranian Gas Refineries. A gas refinery has a complicated process and ongoing projects are directly or indirectly linked with continuous production in this industry. Consequently managing the project time is a critical issue and considering the very low reliability of the project planning with certainty, using more secure models for control and interact with uncertainty is a necessity. It is obvious that successful project time management should be based on comprehensive time estimation. Therefore, considering the uncertainty in the estimation of project time is the main object. From the above discussion, the following conclusions were derived:

1. Uncertainties that affect the project time are based on probability and possibility theories. Many industries, such as gas refineries manage probable uncertainties in their projects by risk management but in the field of possible uncertainties, actions are very scarce. It implies on the fault that there is an urgent necessity to re-arrange the project time estimation model mix, with all modes integrated into a seamless time management system having smart interfacing among them.

2. This research considered the managing of possible uncertainties in gas refineries projects by Fuzzy Critical Path Method. Simultaneously, providing a database of project risks based on previous experience of construction projects in gas refineries was placed on the agenda.

3. Finally, a precise model was proposed to provide comprehensive project time estimation. The proposed model integrates the risk management and fuzzy expert systems in order to manage both modes of time uncertainty in the construction project of Iranian gas refineries.

4. The result of the implementation of proposed model shows that the accuracy of project time estimation increases about 8 to 24 percent. Finally, due to successful results of this research, it has been suggested that the proposed model could be generalized to other industries projects.

\section{References}

[1] S. Ward and C. Chapman, "Transforming project risk management into project uncertainty management," International Journal of Project Management, vol. 21, no. 2, pp. 97-105, 2003.

[2] M. El-Cheikh, A. H. C. Chan, and J. Lamb, "Risk analysis between possible and probable," Risk Analysis V: Simulation and Hazard Mitigation, vol. 1, pp. 3-12, 2006.

[3] AIRMIC, "Structured approach to enterprise risk management (ERM) and the requirements of ISO 31000," The Association of Insurance and Risk Managers, London, UK, 2010.

[4] A. Naderpour, M. Mofid, and J. Majrouhi Sardrood, "State-of-the-art review on risk modeling and assessment in construction projects - from 1983 to 2015," presented at Enterprise Risk management Conference, Tehran, 2015.

[5] A. Naderpour and M. Mofid, "Improving construction management of an educational center by applying earned value technique," Journal of Procedia engineering, vol. 14, pp. 1945-1952, 2011.

[6] E. Hadavandi, H. Shavandi, and A. Ghanbari, "Integration of genetic fuzzy systems and artificial neural networks for stock price forecasting," Journal of Knowledge-Based Systems, vol. 23, no. 8, pp. 800808, 2010.

[7] H. Shavandi and H. Mahlooji, "Fuzzy hierarchical queuing models for the location set covering problem in congested systems," Journal of Scientia Iranica, vol. 15, no. 3, pp. 378-388, 2008.

[8] F. Choobineh and H. Li, "An index for ordering fuzzy numbers," Journal of Fuz:y Sets and Systems, vol. 54, no. 3, pp. 287-294, 1993.

[9] R. Yager, "A procedure for ordering fuzzy subsets of the unit interval," Journal of Information Sciences, vol. 24, no. 2, pp. 143-161, 1981.

[10] C. H. Cheng, "A new approach for ranking fuzzy numbers by distance method," Fu₹zy Sets and Systems, vol. 95, no. 3, pp. 307-317, 1998.

[11] S. M. Chen and K. Sanguansat, "Analyzing fuzzy risk based on a new fuzzy ranking method between generalized fuzzy numbers," Expert Systems with Applications, vol. 38, no. 3, pp. 2163-2171, 2011.

[12] S. Abbasbandy and T. Hajjari, "A new approach for ranking of trapezoidal fuzzy numbers," Computers \& Mathematics with Applications, vol. 57, no. 3, pp. 413-419, 2009.

[13] S. Chanas and P. Zieliński, "Critical path analysis in the network with fuzzy activity times," Fuz:y Sets and Systems, vol. 122, no. 2, 195-204, 2001. 
[14] I. Gazdik, "Fuzzy-network planning-FNET," IEEE Transactions on Reliability, vol. 32, no. 3, pp. 304313, 1983.

[15] A. Kaufmann and M. Gupta, Introduction to Fu₹ry Arithmetic Theory and Applications. New York: Van Nostrand Reinhold, 1991.

[16] C. S. McCahon and E. S. Lee, "Project network analysis with fuzzy activity times," Computers \& Mathematics with Applications, vol. 15, no. 10, pp. 829-838, 1988.

[17] S. H. Nasution, "Fuzzy critical path method," IEEE Transactions on Systems, Man, and Cybernetics, vol. 24, no. 1, pp. 48-57, 1994.

[18] C. H. Cheng, "Evaluating weapon systems using ranking fuzzy numbers," Fu₹:y sets and systems, vol. 107, no. 1, pp. 25-35, 1999.

[19] P. Lorterapong, O. Moselhi, "Project-network analysis using fuzzy sets theory," Journal of Construction Engineering and Management, vol. 122, no. 4, pp. 308-318, 1996.

[20] J. S. Yao and F. T. Lin, "Fuzzy critical path method based on signed distance ranking of fuzzy numbers," IEEE Transactions on Systems, Man, and Cybernetics-Part A: Systems and Humans, vol. 30, no. 1, pp, 76-82, 2000.

[21] S. Chanas and P. Zieliński, "Critical path analysis in the network with fuzzy activity times," Fuz:y Sets and Systems, vol. 122, no. 2, pp. 195-204, 2001.

[22] M. Blue, B. Bush, and J. Puckett, "Unified approach to fuzzy graph problems," Fuz:y Sets and Systems, vol. 125, no. 3, pp. 355-368, 2002.

[23] D. Kuchta, "Use of fuzzy numbers in project risk (criticality) assessment," International Journal of Project Management, vol. 19, no. 5, pp. 305-310, 2001.

[24] F. T. Lin and J. S. Yao, "Fuzzy critical path method based on signed-distance ranking and statistical confidence-interval estimates," The Journal of Supercomputing, vol. 24, no. 3, pp. 305-325, 2003.

[25] D. Dubois, H. Fargier, and V. Galvagnon, "On latest starting times and floats in activity networks with ill-known durations," European Joumal of Operational Research, vol. 147, no. 2, pp. 266-280, 2003.

[26] G. S. Liang and T. C. Han, "Fuzzy critical path for project network," Information and Management Sciences, vol. 15, no. 4, pp. 29-40, 2004.

[27] A. V. O. Oliveros and A. R. Fayek, "Fuzzy logic approach for activity delay analysis and schedule updating," Journal of Construction Engineering and Management, vol. 131, no. 1, pp. 42-51,2005.

[28] P. Zieliński, "On computing the latest starting times and floats of activities in a network with imprecise durations," Fuz:y Sets and Systems, vol. 150, no. 1, pp. 53-76, 2005.

[29] T. C. Han, C. C. Chung, and G. S. Liang, "Application of Fuzzy Critical Path Method to Aipport," Journal of Marine Science and Technology, vol. 14, no. 3, pp. 139-146.

[30] S. M. Chen and J. H. Chen, "Fuzzy risk analysis based on ranking generalized fuzzy numbers with different heights and different spreads," Expert Systems with Applications, vol. 36, no. 3, pp. 6833-6842, 2009.

[31] H. J. Ho and T. C. Chen, "Motorized CPM/CAM physiotherapy device with sliding-mode fuzzy neural network control loop,"Computer Methods and Programs in Biomedicine, vol. 96, no. 2, pp. 96-107, 2009.

[32] A. Kumar and P. Kaur, "A new method for fuzzy critical path analysis in project networks with a new representation of triangular fuzzy numbers," Applications and Applied Mathematics: An International Joumal, vol. 5, no. 10, pp. 1442-1466, 2010.

[33] S. H. Yakhchali and S. H. Ghodsypour, "On the latest starting times and criticality of activities in a network with imprecise durations," Applied Mathematical Modelling, vol. 34, no. 8, pp. 2044-2058, 2010.

[34] S. Sathish and K. Ganesan, "Fully fuzzy time-cost trade-off in a project network-A new approach," Mathematical Theory and Modeling, vol. 2, pp. 53-65, 2012.

[35] P. P. Bushan Rao and N. Ravi Shankar, "Fuzzy critical path analysis based on the centroid of centroids of fuzzy numbers and new subtraction method," International Journal of Mathematics in Operational Research, vol. 5, no. 2, pp. 205-224, 2013.

[36] R. Morovatdar, A. Aghaie, E. Roghanian, and A. A. Haddad, "An algorithm to obtain possibly critical paths in imprecise project networks," Iranian Journal of Operations Research, vol. 4, no. 1, pp. 39-54, 2013.

[37] S. Elizabeth and L. Sujatha, "Project scheduling method using triangular intuitionistic fuzzy numbers and triangular fuzzy numbers," Applied Mathematical Sciences, vol. 9, no. 1-4, pp. 185-198, 2015.

[38] A. Kazemi, A. Talebi, and M. J. Oroojeni, "Analysis of critical paths in a project network with random fuzzy activity times," Amirkabir International Journal of Modeling, Identification, Simulation \& Control, vol. 48, no. 2, pp. 93-102, 2016. 
[39] F. Jalaee and A. Mahdaviparsa, "Risk management in Iranian Construction Projects," presented at 6th International Conference on Project Management, Tehran, 2010.

[40] R. Soltani, M. Ebrahim-Zadeh, and G. H. Halvani, "Risk assessment in Shiraz refinery by FMEA method," Journal of Iran Occupational Medicine, vol. 3, no. 2, pp. 16-23, 2011.

[41] A. Alamtabriz and E. Hamzehi, "Project Risk Evaluation and Analysis Using Risk Management Based on PMBOK Standard and RFMEA Technique," Journal of Industrial Management Studies, vol. 9, no. 23, pp. 1-19, 2012.

[42] L. Amanatyazdi and N. Moharramnejad, "Risk management in Iranian Oil Company," Journal of Environmental Studies, vol. 39, no. 2, pp. 61-72, 2013.

[43] A. Bordbar and M. Sayebani, "Identification and allocation of risks in construction projects," presented at First National Conference on Construction Project Management, Tehran, 2013.

[44] A. Ardeshir, M. Mohajeri, and M. Amiri, "Safety assessment in construction projects based on analytic hierarchy process and grey fuzzy methods," Iran Occupational Health, vol. 11, no. 2, pp. 87-98, 2014.

[45] Y. Doosti, S. Khazaei, and P. Rafati, "Risk management in the construction of gas refineries," presented at Iranian Conference of Civil Engineering and Its Acbievements, Iran, 2014.

[46] M. Ansari, M. Minehpour, D. Erfani, and B. Azizian, "Final report of risk management in the construction of Gas pipeline transmission between refineries and gas city stations," Final Repot, Iranian National Gas Company, Iran, 2014.

[47] P. Najafi, H. Haji, and V. Shahhosseini, "Risk quantification in complex and fast projects and impact on the timely completion of the project," presented at International Conference on Management Tools and Techniques, Tehran, 2015.

[48] S. Ghasemi, K. Yavari, R. Mahmoudvand, and B. Sahabi, "Presenting a new method for scrutiny the insurable risk in gas refineries by FMEA," Journal of Economic Policy, vol. 13, no. 7, pp. 1-26, 2015.

[49] J. E. Barlett, J. W. Kotrlik, and C. C. Higgins, "Determining appropriate sample size in survey research," Information Technology, Learning, and Performance Journal, vol. 1, no. 43, 2001. 